\title{
Analisis Kondisi Eksisting Jaringan Pipa Distribusi Air Bersih Kelurahan Simpang Rumbio, PDAM Kota Solok
}

\author{
Ridwan \\ Fakultas Teknik, Universitas Andalas \\ Koresponden email : ridwan@eng.unand.ac.id
}

Diterima: 26 Juni 2019

Disetujui: 12 Juli 2019

\begin{abstract}
This research is intended to determine the hydraulic conditions of the clean water distribution network in Simpang Rumbio Village by Solok City PDAM, in order to resolve water problems that often do not flow in the city border area and its surroundings. PDAM Solok City must be able to meet customers' clean water needs from aspects of quality, quantity and continuity. From the data of active customers of PDAM Kota Solok in 2018, the average level of clean water usage is 806 liters / customer / month or 130 liters / person / day, with an average water loss rate of $43.17 \%$. The nodes included in Epanet 2.0 Software are 7 nodes, with the initial node $\mathrm{P}$ being a reservoir equipped with a capacity distribution pump of 30 liters / second and a head of 60 meters around the CEC IPA area. The six other nodes are the point of collection for active customers in Simpang Rumbio Subdistrict as many as 1,547 customers with a total distribution pipe length of 6,300 meters Epanet 2.0 analysis results, there is a negative pressure on node 5 (Prosecutor's Office) $(-0.18)$ meters and node 6 (Saok Laweh) $(-4,5)$ meters. The alternative solution is by replacing pipe 4 from a diameter of $100 \mathrm{~mm}$ to $150 \mathrm{~mm}$ type PVC, or increasing the specifications of the pump head to 70-80 meters
\end{abstract}

Keywords: water usage, water loss, distribution network, epanet 2.0, negative pressure, PDAM

\begin{abstract}
Abstrak
Penelitian ini bertujuan untuk mengetahui kondisi hidrolis jaringan distribusi air bersih di Kelurahan Simpang Rumbio oleh PDAM Kota Solok, guna penyelesaian masalah air yang sering tidak mengalir di wilayah perbatasan kota dan sekitarnya. PDAM Kota Solok harus mampu memenuhi kebutuhan air bersih pelanggan dari aspek kualitas, kuantitas dan kontinuitas. Rata-rata tingkat pemakaian air bersih pelanggan tahun 2018 sebesar 806 liter/pelanggan/bulan atau 130 liter/orang/hari, dengan tingkat kehilangan air rata-rata 43,17\%. Node yang dimasukan pada Sofware Epanet 2.0 ini berjumlah 7 node, dengan node awal P adalah reservoar yang dilengkapi dengan pompa distribusi kapasitas 30 liter/detik dan head 60 meter di sekitar wilayah IPA KTK. Adapun enam node lainnya merupakan titik pengambilan untuk pelanggan aktif di Kelurahan Simpang Rumbio sebanyak 1.547 pelanggan dengan total panjang pipa distribusi adalah 6.300 meter. Hasil analisis Epanet 2.0, terdapat tekanan negatif pada node 5 (Kantor Kejaksaan) sebesar -0,18 meter dan node 6 (Saok Laweh) sebesar $-4,5$ meter. Alternatif penyelesaiannya dengan penggantian pipa 4 dari diameter $100 \mathrm{~mm}$ menjadi $150 \mathrm{~mm}$, atau meningkatkan spesifikasi head pompa menjadi 70-80 meter.
\end{abstract}

Kata kunci : pemakaian air, kehilangan air, jaringan distribusi, epanet 2.0, tekanan negatif, PDAM.

\section{Pendahuluan}

Kinerja PDAM Kota Solok di wilayah pelayanan Kelurahan Simpang Rumbio, saat ini masih belum optimal khususnya daerah paling ujung dari jaringan distribusi yaitu komplek perkantoran Kejaksaan Negeri Solok dan Nagari Saok Laweh yang terletak di batas kota. Indikasi keterbatasan pelayanan ini salah satunya terlihat dari pasokan air bersih PDAM Kota Solok ke wilayah tersebut dengan kondisi tekanan yang relatif rendah sehingga tidak dapat mencapai bak air di rumah pelanggan. Kondisi ini sering menimbulkan keresahan pelanggan dan menjadi tunggakan laporan pengaduan di PDAM Kota Solok yang belum diselesaikan. Oleh sebab itu, upaya menganalisis jaringan distribusi pada Kelurahan Simpang Rumbio, merupakan salah satu kegiatan prioritas diawal yang harus dilakukan oleh PDAM Kota Solok dalam merumuskan penyelesaian permasalahan tersebut. Pada penelitian ini akan dilakukan analisis kondisi eksisting jaringan distribusi pada kawasan tersebut menggunakan Sofware Epanet 2.0 dengan sumber air bersih berasal dari reservoar pada Unit Instalasi Pengolahan Air Bersih (IPA) di 

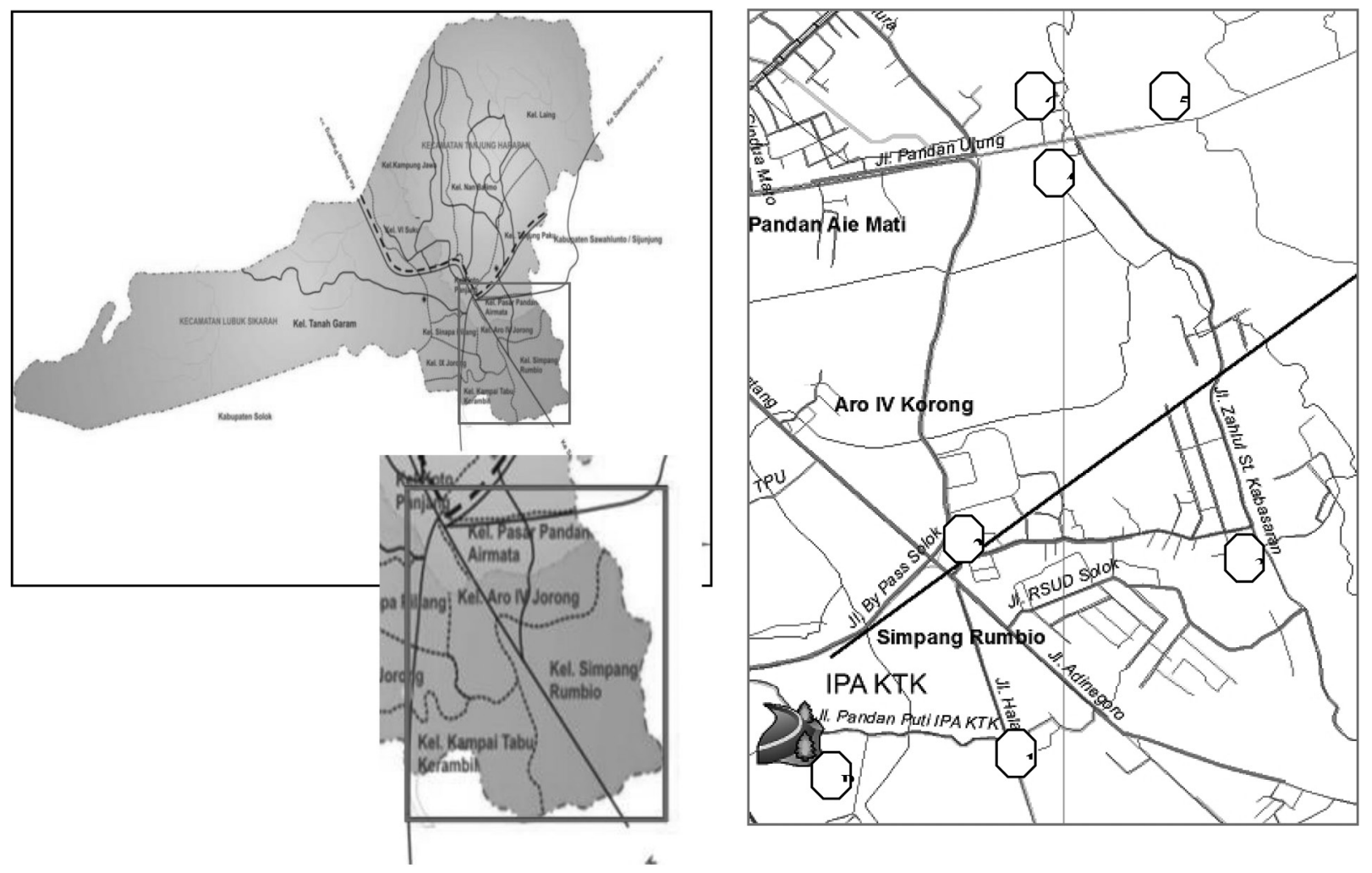

Gambar 1. Wilayah penelitian Kelurahan Simpang Rumbio pada peta administrasi Kota Solok Sumber: Bagian Teknik - PDAM Kota Solok (2018)

Kelurahan KTK dengan sistem pompa kapasitas 30 liter/detik dan head 60 meter.

\section{Kondisi Eksisting}

Secara umum penduduk yang terlayani oleh PDAM Kota Solok saat ini adalah sebanyak 73.106 jiwa atau $92,77 \%$ (persen) dari jumlah penduduk Kota Solok sebesar 78.806 jiwa. Jumlah pelanggan PDAM kota Solok tahun 2018 adalah 14.606 pelanggan aktif atau naik sebesar 2,71\% dari tahun 2017, yakni 14.221 pelanggan aktif. Untuk Kelurahan Simpang Rumbio yang menjadi wilayah penelitian ini terdapat 1.547 pelanggan aktif dari 13 kelurahan yang dilayani oleh PDAM Kota Solok. Penyediaan air bersih Kelurahan Simpang Rumbio menggunakan sistem pompa kapasitas 30 liter/detik dengan head 60 meter yang sumber airnya berasal dari IPA yang berada di Kelurahan KTK. Adapun deskripsi wilayah jaringan distribusi pelayanan Kelurahan Simpang Rumbio ini dapat di deskripsikan sebagai berikut pada Gambar 1.

Titik atau node yang dideskripsikan pada Gambar 1. adalah titik tapping atau lokasi pengambilan yang berupa cabang pipa distribusi untuk mendistribusikan air bersih kepada sejumlah pelanggan yang tersebar di wilayah pelayanan. Adapun rincian keterangan titik atau node itu disajikan oleh Tabel 1. dibawah ini.

Data PDAM Kota Solok selama tahun 2018, tentang jumlah air produksi, air distribusi dan air terjual yang dicatat di 14.606 meteran pelanggan disajikan oleh Tabel 2. Air yang terjual merupakan tingkat pemakaian air bersih dari pelanggan itu sendiri. Sedangkan selisih jumlah air bersih yang diproduksi dengan jumlah air yang didistribusikan dan terjual, merupakan besaran nilai kehilangan air yang terdapat di pipa jaringan distribusi PDAM Kota Solok.

\section{Tinjauan Pustaka}

\section{a. Air Bersih}

Mengacu kepada Peraturan Menteri Kesehatan Republik Indonesia No.416/Menkes/PER/ IX/1990, maka air bersih dapat diartikan sebagai air yang dimanfaatkan oleh manusia untuk memenuhi kebutuhannya sehari-hari (Moegijantoro, 1996). Untuk kebutuhan lanjutannya sebagai air minum, maka air bersih tersebut dimasak terlebih dahulu untuk memenuhi syarat yang diperbolehkan dari segi parameter fisik, kimia, biologi dan radiologis. Air bersih ini dapat berasal dari berbagai macam sumber air baku yang tersedia disekitar lingkungan manusia itu sendiri, antara lain: dari air permukaan, seperti air sungai, air danau, embung, waduk dan genangan air lainnya di permukaan bumi, air hujan, air tanah 
dangkal dan air tanah dalam dan mata air. Untuk menentukan alternatif sumber air baku yang akan digunakan untuk memproduksi air bersih, maka perlu diperhatikan aspek kualitas, kuantitas dan kontinuitas sumber air baku itu sendiri (Linsley dan Franzini, 1985).

b. Persyaratan dan Kriteria Penyediaan Air Bersih

Dalam sistem penyediaan air bersih, aspek kualitas merupakan deskripsi mutu dari air bersih itu sendiri yang meliputi parameter fisik, parameter kimiawi, bakteriologis dan radioaktif, dan semua parameter itu harus terpenuhi pada sistem penyediaan air bersih masyarakat (Kamala, A dan Rao, Kanth. 1988). Sedangkan dari aspek kuantitas atau debit aliran yang disalurkan kepada masyarakat merupakan deskripsi dari jumlah ketersediaan air bersih itu sendiri dalam memenuhi kebutuhan masyarakat dalam suatu kawasan. Dalam artian lain, air baku terpilih untuk memenuhi kebutuhan air bersih masyarakat harus sesuai dengan tingkat pelayanan yang akan direncanakan pada suatu kawasan. Kebutuhan air bersih yang dimaksud dalam penelitian ini adalah banyak air bersih yang dibutuhkan oleh sebuah kawasan untuk aktifitas rumah tangga atau disebut juga dengan kebutuhan domestik, dan kebutuhan non domestik yang harus terpenuhi pada setiap waktu. Jumlah kebutuhan air bersih untuk keperluan rumah tangga atau domestik pada suatu kawasan disajikan di Tabel (Noerbambang, S.M.Morimura, 1993). Sedangkan standar kebutuhan air untuk keperluan diluar aktifitas rumah tangga atau dikenal juga dengan non domestik pada sebuah kawasan, merupakan kebutuhan air bersih untuk keperluan di luar keperluan non domestik pada suatu kawasan, seperti: aktifitas di sarana prasarana pendidikan, perkantoran, pusat bisnis, pasar dan pertokoan, dan aktitas lainnya yang terdapat pada suatu kawasan. Besaran nilai kebutuhan air bersih untuk keperluan non domestik ini, disajikan di Tabel 4 (NSPM Kimpraswil, 2002).

Untuk aspek kontinuitas, sistem penyediaan air bersih yang ada di sebuah kawasan haruslah bersifat terus menerus dan tersedia di sepanjang waktu. Sifat kontinuitas mencerminkan bahwasanya air baku untuk kebutuhan air bersih dipastikan dapat diambil sepanjang waktu dengan fluktuasi aliran yang relatif konstan, di saat musim kemarau atau musim hujan. Sedangkan untuk kondisi hidrolis di daerah pelayanan, tekanan air yang tersedia pada pipa jaringan utama tidak melebihi 10-80 $\mathrm{m}$ dengan kecepatan aliran dalam pipa adalah $0,6-3 \mathrm{~m} / \mathrm{s}$. Kondisi diatur oleh Pedoman

Tabel 1. Titik atau Node pada jaringan eksisting distribusi utama air bersih Kelurahan Simpang Rumbio, PDAM Kota Solok

\begin{tabular}{|c|c|c|c|c|}
\hline Titik (Node) & Jumlah & Spesifikasi & Elevasi & Pelanggan \\
\hline $\begin{array}{l}\text { P adalah Pompa Reservoir di IPA } \\
\text { Sebagai Titik Awal Jaringan }\end{array}$ & $\begin{array}{l}\mathrm{Q}=30 \\
\text { Head }=60\end{array}$ & $\begin{array}{l}\text { Liter/detik } \\
\text { Meter }\end{array}$ & $401 \mathrm{~m} \mathrm{dpl}$ & \\
\hline $\begin{array}{r}\text { 1. Simpang Baringin Rambak } \\
\text { Diameter Pipa ( } \varnothing) \\
\text { Panjang Pipa (L) }\end{array}$ & $\begin{array}{l}200 \\
1.000 \\
\end{array}$ & $\begin{array}{l}\mathrm{mm} \text { PVC } \\
\text { Meter (pipa } \mathrm{P}-1)\end{array}$ & $401 \mathrm{~m} \mathrm{dpl}$ & $\begin{array}{c}263 \text { SR } \\
\text { (sambungan } \\
\text { rumah) }\end{array}$ \\
\hline $\begin{array}{l}\text { 2. Mesjid Syukur } \\
\qquad \begin{array}{r}\text { Diameter Pipa ( } \varnothing) \\
\text { Panjang Pipa (L) }\end{array}\end{array}$ & $\begin{array}{l}150 \\
500 \\
\end{array}$ & $\begin{array}{l}\text { mm PVC } \\
\text { Meter (pipa 1-2) }\end{array}$ & $402 \mathrm{~m} \mathrm{dpl}$ & $511 \mathrm{SR}$ \\
\hline $\begin{array}{r}\text { 3. Simpang 3 Sarang Walet } \\
\text { Diameter Pipa ( } \varnothing) \\
\text { Panjang Pipa (L) }\end{array}$ & $\begin{array}{l}150 \\
1.000 \\
\end{array}$ & $\begin{array}{l}\text { mm PVC } \\
\text { Meter (pipa 2-3) }\end{array}$ & $402 \mathrm{~m} \mathrm{dpl}$ & $309 \mathrm{SR}$ \\
\hline $\begin{array}{lr}\text { 4. Batas Kota } & \\
& \text { Diameter Pipa ( } \varnothing) \\
& \text { Panjang Pipa (L) } \\
\end{array}$ & $\begin{array}{l}100 \\
1.400 \\
\end{array}$ & $\begin{array}{l}\text { mm PVC } \\
\text { Meter (pipa 3-4) }\end{array}$ & $403 \mathrm{~m} \mathrm{dpl}$ & $232 \mathrm{SR}$ \\
\hline $\begin{array}{r}\text { 5. Kantor Kejaksaan } \\
\text { Diameter Pipa ( }(\text { ) } \\
\text { Panjang Pipa (L) }\end{array}$ & $\begin{array}{l}75 \\
1.300 \\
\end{array}$ & $\begin{array}{l}\text { mm PVC } \\
\text { Meter (pipa 4-5) }\end{array}$ & $403 \mathrm{~m} \mathrm{dpl}$ & $124 \mathrm{SR}$ \\
\hline $\begin{array}{r}\text { 6. Walinagari Saok Laweh } \\
\text { Diameter Pipa ( } \varnothing) \\
\text { Panjang Pipa (L) }\end{array}$ & $\begin{array}{l}75 \\
1.100 \\
\end{array}$ & $\begin{array}{l}\text { mm PVC } \\
\text { Meter (pipa 5-6) }\end{array}$ & $403 \mathrm{~m} \mathrm{dpl}$ & $108 \mathrm{SR}$ \\
\hline
\end{tabular}

Sumber: Bagian Teknik, PDAM Kota Solok, 2018 
Tabel 2. Rekapitulasi produksi, distribusi dan air terjual PDAM Kota Solok tahun 2018

\begin{tabular}{|c|c|c|c|c|c|c|c|c|}
\hline \multirow[t]{2}{*}{ No } & \multirow[t]{2}{*}{ Uraian } & \multirow{2}{*}{$\begin{array}{c}\text { Air } \\
\text { Produksi } \\
\left(\mathrm{m}^{3}\right)\end{array}$} & \multirow{2}{*}{$\begin{array}{c}\text { Air } \\
\text { Distribusi } \\
\left(\mathrm{m}^{3}\right)\end{array}$} & \multirow{2}{*}{$\begin{array}{c}\text { Air } \\
\text { Terjual } \\
\left(\mathrm{m}^{3}\right)\end{array}$} & \multicolumn{2}{|c|}{ Kebocoran Produksi } & \multicolumn{2}{|c|}{ Kebocoran Distribusi } \\
\hline & & & & & $\left(\mathrm{m}^{3}\right)$ & $\%$ & $\left(\mathrm{~m}^{3}\right)$ & $\%$ \\
\hline 1. & Januari & 609.532 & 584.536 & 354.663 & 24.996 & 4,1 & 229.873 & 39,33 \\
\hline 2. & Februari & 599.523 & 567.562 & 324.994 & 31.961 & 5,3 & 242.568 & 42,74 \\
\hline 3 . & Maret & 630.840 & 589.851 & 346.710 & 40.989 & 6,5 & 243.141 & 41,22 \\
\hline 4. & April & 619.512 & 591.766 & 357.601 & 27.746 & 4,5 & 234.165 & 39,57 \\
\hline 5 & Mei & 624.108 & 597.429 & 343.634 & 26.679 & 4,3 & 253.795 & 42,48 \\
\hline 6. & Juni & 619.513 & 597.429 & 352.092 & 22.084 & 3,6 & 245.337 & 41,07 \\
\hline 7. & Juli & 620.025 & 591.774 & 381.949 & 28.251 & 4,6 & 209.825 & 35,46 \\
\hline 8. & Agustus & 603.501 & 590.482 & 361.935 & 13.019 & 2,2 & 228.547 & 38,71 \\
\hline 9. & September & 596.036 & 584.745 & 366.534 & 11.291 & 1,9 & 218.211 & 37,32 \\
\hline 10. & Oktober & 619.389 & 593.388 & 365.011 & 26.001 & 4,2 & 228.377 & 38,49 \\
\hline 11. & November & 597.569 & 577.834 & 378.320 & 19.735 & 3,3 & 199.514 & 34,53 \\
\hline 12 & Desember & 617.488 & 589.011 & 364.963 & 28.477 & 4,6 & 224.048 & 38,04 \\
\hline & Total & 7.357 .036 & 7.055 .807 & 4.298 .406 & 301.229 & 4,3 & 2.757 .401 & 39,08 \\
\hline
\end{tabular}

Sumber: Bagian Teknik, PDAM Kota Solok

Teknis dan Pengembangan Sistem Penyediaan Air Minum, 2007. Kondisi tekanan dengan nilai yang kurang atau minus, dapat mengakibatkan aliran air bersih ke pelanggan menjadi tidak mengalir, dan sebaliknya tekanan air yang sangat kuat dapat mengakibatkan terjadinya putusnya koneksi pipa, bocor, pukulan air yang dapat menimbulkan kerusakan pada instrumen atau peralatan pipa, seperti: gate valve, air valve dan lain-lain (Ranald V. Giles, 1984).

\section{c. Sistem Distribusi Air Bersih.}

Pada sistem atau jaringan distribusi air bersih, sistem yang ada secara langsung berkaitan dengan pelanggan, dengan fungsi utama adalah mendistribusikan air bersih dengan kualitas yang telah dipersyaratkan dan memenuhi syarat teknis di seluruh wilayah pelayanan. Sistem dimaksud merupakan komponen dari sistem perpipaan dengan perlengkapannya, seperti:, tekanan sisa yang tersedia, sistem pemompaan (kondisional), dan reservoir distribusi, serta hidran kebakaran (Enri Damanhuri,1989).

\section{Metodologi}

Data atau informasi yang dikumpulkan dalam penelitian ini terdiri dari 2 kelompok data, yaitu:

1. Data yang langsung diperoleh dari pengukuran dengan menggunakan alat ukur atau sejenisnya oleh peneliti termasuk data yang bersifat kualitas atau deskriptif menggunakan pengamatan langsung, yang dinamakan dengan kelompok data primer,

2. Kelompok data yang diperoleh secara tidak langsung oleh peneliti melalui data dasar (data base) dari dinas atau unit kerja yang membidangi, referensi atau tinjauan pustaka, yang dikelompokkan sebagai data sekunder.

Perolehan data primer pada penelitian ini, dilakukan dengan proses penjelajahan atau tracking jalur pipa distribusi eksiting untuk memperoleh data terkait dengan panjang pipa, jenis pipa, diameter pipa, serta elevasi. Tracking yang dilakukan dilapangan juga bertujuan mengkonfirmasi kesesuaian data sekunder yang diperoleh dengan kondisi dilapangan. Sedangkan data sekunder dalam bentuk data konsumen, deskripsi umum wilayah, peta wilayah, serta batas wilayah pelayanan di Kelurahan Simpang Rumbio, di dapat dari PDAM Kota Solok.

Pengukuran elevasi pada setiap titik pengambilan atau tapping yang berupa cabang dari pipa utama pada titik atau node pada penelitian, menggunakan peralatan GPS (Global Positioning System) dan sejenisnya. Proses yang dilakukan adalah setiap titik tapping yang berupa cabang dari pipa utama adalah dengan meletakkan alat GPS tersebut di permukaan tanah untuk mengetahui informasi ketinggian titik tersebut dari permukaan laut, dengan satuan meter dari permukaan laut (mdpl). Sedangkan jarak dari titik atau node satu dengan yang lainnya diukur dengan meteran berjalan yang mengikuti jalur perpipaan yang telah terpasang.

Data debit aliran air yang digunakan pada analisis jaringan eksisting distribusi ini, lebih ditekankan kepada data pemakaian rata-rata air pelanggan yang tercatat pada laporan PDAM Kota Solok dalam bentuk Daftar Rekening Ditagih (DRD) tiap bulannya, serta melakukan perbandingan dengan NSPM Kimpraswil, 2002. Jika dalam perbandingannya, nilai pemakaian eksisting lebih besar dari NSPM Kimpraswil, 2002 sebagaimana Tabel 3, maka yang digunakan dalam analisis jaringan adalah data pemakaian air bersih eksisting, mengingat sistem telah terbangun dan 
mendekati kondisi objektif di lapangan dan begitu sebaliknya. Debit aliran dalam pipa air yang berasal dari pemakaian rata-rata pelanggan dikalikan dengan jumlah pelanggan aktif yang terdapat pada masing-masing titik atau node pengambilan yang berupa cabang pipa utama. Kehilangan air rata-rata yang disajikan pada Tabel 2 menjadi faktor pengali pada perhitungan debit aliran yang akan digunakan. Mengingat yang dianalisis adalah jaringan distribusi, maka debit aliran air yang dihasilkan dari pemakaian rata-rata dengan perkalian faktor jam puncak (Sarwoko, M. 1985).

Evaluasi jaringan distribusi pada penelitian ini menggunakan program Epanet versi 2.0 dengan mekanisme menginput data yang sudah di dapatkan dari hasil penjelajahan jalur pipa sebagaimana ditampilkan oleh Tabel.1, dan debit aliran pada masing-masing cabang pipa utama (Rossman, Lewis A. 2000). Hasil input data tersebut dapat disimulasi dalam program Epanet versi 2.0 dan akan memberikan informasi hidrolis dari operasional jaringan distribusi utama air bersih Kelurahan Simpang Rumbio sampai Batas Kota. Analisis jaringan pipa distribusi pada penelitian ini tidak ditujukan untuk rencana pengembangan pada periode desain, sebaliknya lebih ditujukan mengevaluasi profil hidrolis kondisi jaringan eksisting, untuk menyelesaikan persoalan pengaduan pelanggan yang ada saat ini dalam jangka waktu yang pendek.

\section{Hasil dan Pembahasan}

\section{a. Analisis Data Topografi}

Pengukuran ketinggian lokasi menggunakan alat ukur GPS atau sejenisnya dengan cara memposisikan GPS tersebut di permukaan tanah, serta membaca dan mencatat nilai ketinggian lokasi yang ditampilkan pada layar GPS. Pengambilan data dilakukan pada

Tabel 3. Kriteria perencanaan sistem penyediaan air bersih berdasarkan klasifikasi wilayah

\begin{tabular}{|c|c|c|c|c|c|c|}
\hline No & Parameter & Metro & Besar & Sedang & Kecil & Desa \\
\hline 1. & Tingkat Pelayanan & $100 \%$ & $100 \%$ & $100 \%$ & $100 \%$ & $80 \%$ \\
\hline 2. & $\begin{array}{l}\text { Tingkat Pemakaian Air (L/orang/hari) } \\
-\quad \text { SR } \\
-\quad \text { HU/KU }\end{array}$ & $\begin{array}{c}190 \\
30\end{array}$ & $\begin{array}{c}170 \\
30\end{array}$ & $\begin{array}{c}150 \\
30\end{array}$ & $\begin{array}{c}130 \\
30\end{array}$ & $\begin{array}{c}60-80 \\
30\end{array}$ \\
\hline 3. & Kebutuhan Non Domestik & & & & & \\
\hline & $\begin{array}{l}\text { Industri } \\
\text { Berat } \\
\text { Sedang } \\
\text { Ringan }\end{array}$ & $\begin{array}{l}0,0 \\
0,2 \\
0,1\end{array}$ & $\begin{array}{l}00 \\
, 50 \\
, 25\end{array}$ & $\begin{array}{l}15 \%-30 \\
\text { domestik }\end{array}$ & dari keb & \\
\hline & $\begin{array}{l}\text { Komersial: } \\
\text { Pasar (L/detik/ha) } \\
\text { Hotel (L/kamar/hari) } \\
\text { Lokal } \\
\text { Internasional }\end{array}$ & & & & & \\
\hline & $\begin{array}{l}\text { Sosial dan Institusi } \\
\text { Universitas (L/o/hari) } \\
\text { Sekolah (L/o/hari) } \\
\text { Masjid (m3/hari/unit) } \\
\text { Rumah Sakit (L/tt/hari) } \\
\text { Puskesmas (m3/hari/unit) } \\
\text { Kantor (L/detik/hari) } \\
\text { Militer (m3/hari/ha) }\end{array}$ & & & & & \\
\hline 4. & Kebutuhan Hari Rata-rata & \multicolumn{5}{|c|}{ Kebutuhan Domestik + Non Domestik } \\
\hline 5. & Kebutuhan Hari Maksimum & \multicolumn{5}{|c|}{ Kebutuhan rata-rata $\mathrm{x} 1,15-1,20$} \\
\hline 6. & $\begin{array}{l}\text { Kehilangan Air: } \\
\text { * Sistem Baru } \\
\text { * Sistem Lama }\end{array}$ & \multicolumn{5}{|c|}{$\begin{array}{l}* 20 \% \text { x kebutuhan rata2 } \\
* 30 \%-40 \% \text { x kebutuhan rata2 }\end{array}$} \\
\hline 7. & Kebutuhan Jam Puncak & \multicolumn{5}{|c|}{$\begin{array}{l}\text { Kebutuhan rata-rata } x \text { faktor puncak } \\
(1,65-2,00)\end{array}$} \\
\hline
\end{tabular}

Sumber: NSPM Kimpraswil, 2002 
Tabel 4. Air terjual PDAM Kota Solok Tahun 2018

\begin{tabular}{lccc}
\hline \multicolumn{1}{c}{ Bulan } & Jumlah Hari & $\begin{array}{c}\text { Air Terjual } \\
\text { (liter/SR/hari) }\end{array}$ & $\begin{array}{c}\text { Air Terjual } \\
\text { (liter/orang/hari) }\end{array}$ \\
\hline Januari & 31 & 783 & 131 \\
Februari & 28 & 795 & 132 \\
Maret & 31 & 766 & 128 \\
April & 30 & 816 & 136 \\
Mei & 31 & 759 & 126 \\
Juni & 30 & 804 & 134 \\
Juli & 31 & 844 & 141 \\
Agustus & 31 & 799 & 133 \\
September & 30 & 836 & 139 \\
Oktober & 31 & 806 & 134 \\
November & 30 & 863 & 144 \\
Desember & 31 & 806 & 134 \\
\hline \multicolumn{2}{c}{ Rata-rata } & 806 & 134
\end{tabular}

Sumber : Hasil analisis, 2018

setiap titik atau node pengambilan, yaitu titik percabangan pada pipa distribusi utama, dengan rute perjalanan dari Reservoar/Pompa (P) di IPA Kelurahan KTK hingga sepanjang jalur pipa distribusi yang berakhir di batas kota. Berdasarkan survei topografi jaringan tersebut, di dapat hasil 6 titik pengambilan dengan jalur track sepanjang $\pm 6.300 \mathrm{~m}$, dengan elevasi relatif datar, yakni 401sampai 403 meter dari permukaan laut (m dpl).

\section{b. Analisa Pemakaian Air Bersih Pelanggan PDAM Kota Solok}

Dari data air terjual yang disajikan pada Tabel 2, pemakaian rata-rata pelanggan PDAM Kota Solok per bulan di tahun 2018 dengan jumlah pelanggan 14.606 pelanggan aktif, yaitu 806 liter/pelanggan/hari. Jumlah jiwa pada masingmasing pelanggan adalah 6 orang, mengingat Kota Solok terkelompok kepada Kota Kecil sebagaimana Tabel 3, maka pemakaian ratarata pelanggan PDAM Kota Solok adalah 134 liter/orang/hari. Sedangkan angka kehilangan air rata-rata pada jaringan berada pada angka 43,17\%. Jika dibandingkan dengan NSPM Kimpraswil, 2002, maka tingkat pemakaian air bersih pelanggan PDAM Kota Solok telah melebihi angka NSPM Kimpraswil 2002, yaitu : 100 liter/orang/hari. Sedangkan angka kehilangan air telah melebihi nilai kriteria maksimal, yaitu: $30 \%$.

Dalam analisis jaringan pipa eksisting ini, hal yang penting diperhitungkan adalah penentuan besarnya kapasitas aliran pada masing-masing wilayah pelayanan dengan jumlah sambungan aktif yang ada. Besarnya pemakaian air yang menjadi kebutuhan pelanggan untuk di distribusikan di enam titik pengambilan atau penyadapan (tapping) pada pipa distribusi utama ini, tergantung kepada jumlah sambungan pelanggan aktif PDAM yang ada diwilayah masing-masing. Perhitungannya secara lengkap disajikan pada Tabel 5.

\section{c. Analisa Kapasitas Aliran Dalam Jaringan Pipa}

Berdasarkan hasil perhitungan Tabel6, maka debit puncak (Qp) pada masing-masing titik atau node akan menjadi data yang akan dimasukan dalam analisis jaringan melalui Sofware Epanet 2.0. Adapun data elevasi masing-masing titik atau node, panjang pipa yang di dapat dari jarak antara dua titik, diameter dan jenis pipa yang terdapat pada Tabel 1, menjadi data yang diinput ke dalam Sofware Epanet 2.0. Dari berdasarkan Tabel 5 di atas, terlihat besarnya debit aliran pengambilan di masing-masing titik atau node di sepanjang jaringan pipa distribusi, yaitu: maksimal 10 liter/detik di titik 2 dengan total debit aliran yang disuplai oleh pompa ke sistem penyediaan air bersih Kelurahan Simpang Rumbio adalah 30 liter/detik.

\section{d. Analisis Jaringan Distribusi dengan Sofware Epanet 2.0 \\ Sofware Epanet 2.0 yang digunakan dalam}

Tabel 5. Perhitungan debit aliran pada jaringan distribusi kelurahan Simpang Rumbio

\begin{tabular}{|c|c|c|c|c|c|c|c|c|c|}
\hline $\begin{array}{c}\text { Titik } \\
\text { (Node) } \\
\text { P }\end{array}$ & $\begin{array}{l}\text { Jumlah } \\
\text { SR } \\
\text { (Unit) }\end{array}$ & $\begin{array}{c}\text { Pemakaian } \\
\text { Pelanggan } \\
\text { PDAM } \\
\text { (liter/SR/hari) }\end{array}$ & $\begin{array}{c}\text { Jumlah } \\
\text { Pemakaian } \\
\text { (liter/hari) }\end{array}$ & \multicolumn{2}{|c|}{$\begin{array}{l}\text { Kehilangan Air } \\
\text { (liter/hari) }\end{array}$} & $\begin{array}{c}\text { Jumlah } \\
\text { Pemakaian dan } \\
\text { Kehilangan Air } \\
\text { (liter/hari) }\end{array}$ & $\begin{array}{l}\text { faktor } \\
\text { puncak } \\
\text { (fp) }\end{array}$ & $\begin{array}{c}\text { Jumlah } \\
\text { Pemakaian } \\
\text { Puncak } \\
\text { 1/hari }\end{array}$ & $\begin{array}{c}\text { Debit } \\
\text { puncak (Qp) } \\
\text { (liter/detik) }\end{array}$ \\
\hline 1 & 263 & 806 & 211.978 & $43,17 \%$ & 91.511 & 303.489 & 1,5 & 455.233 & 5 \\
\hline 2 & 511 & 806 & 411.866 & $43,17 \%$ & 177.803 & 589.669 & 1,5 & 884.503 & 10 \\
\hline 3 & 309 & 806 & 249.054 & $43,17 \%$ & 107.517 & 356.571 & 1,5 & 534.856 & 6 \\
\hline 4 & 232 & 806 & 186.992 & $43,17 \%$ & 80.724 & 267.716 & 1,5 & 401.575 & 5 \\
\hline 5 & 124 & 806 & 99.944 & $43,17 \%$ & 43.146 & 143.090 & 1,5 & 214.635 & 2 \\
\hline 6 & 108 & 806 & 87.048 & $43,17 \%$ & 37.579 & 124.627 & 1,5 & $\begin{array}{l}186.940 \\
\text { Jumlah }\end{array}$ & $\begin{array}{c}2 \\
30\end{array}$ \\
\hline
\end{tabular}

Sumber : Hasil analisis, 2018 

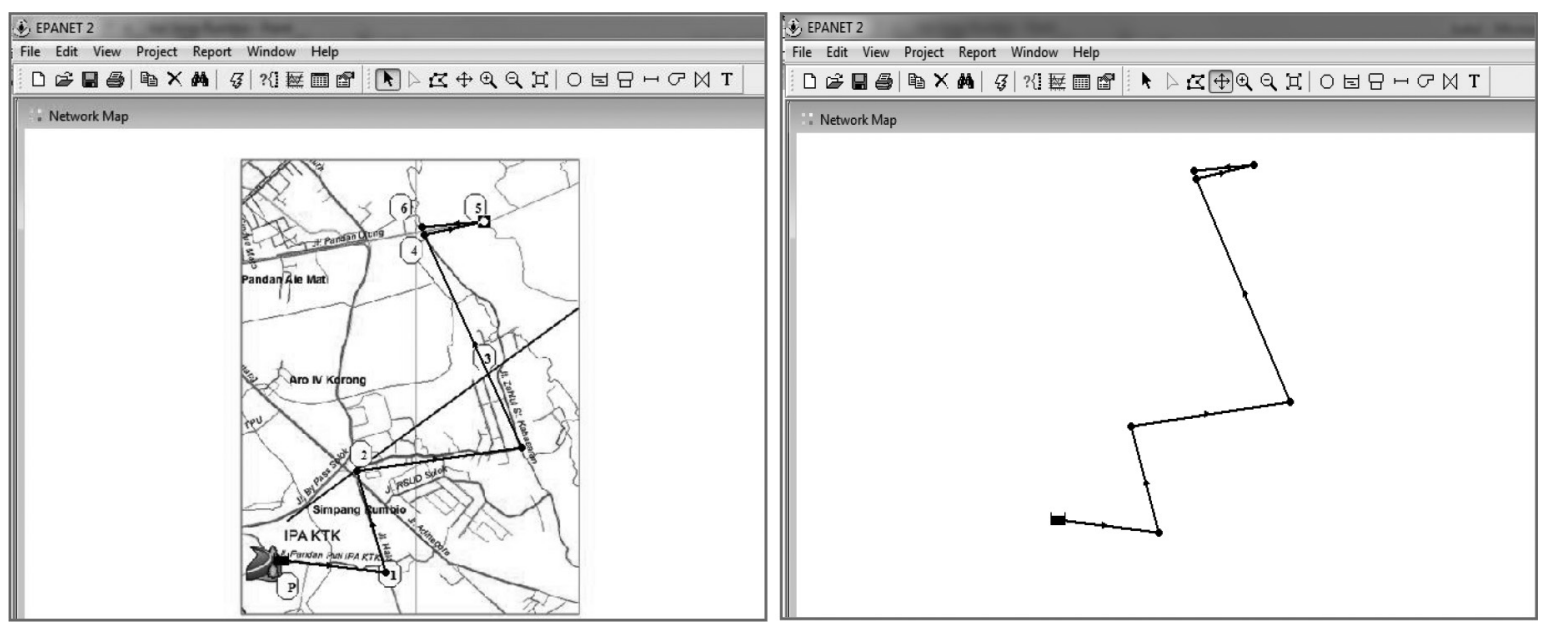

Gambar 2. Layar utama analisis sistem jaringan distribusi air bersih untuk Kelurahan Simpang Rumbio dengan menggunakan Sofware Epanet 2.0

Sumber: Hasil analisis (2018)

menganalisis jaringan distribusi eksisting, memberikan informasi terhadap laju aliran, kecepatan, head losses dan faktor gesek yang digunakan pada pipa, serta sisa tekan atau pressure yang terjadi pada titik atau node yang diamati (Materi Diklat DPU, 1996). Deskripsi atau layar utama analisis sistem jaringan distribusi air bersih untuk Kelurahan Simpang Rumbio dengan menggunakan Sofware Epanet 2.0 disajikan oleh Gambar 2.

Pada Gambar 2. hasil running epanet di atas, menunjukan bahwa terdapat tekanan negatif pada 2 titik ujung pipa distribusi (batas kota), yaitu: Titik 5 (Kantor Kejaksaan) dengan nilai (-) minus 0,18 meter dan Titik 6 (Saok Laweh) dengan nilai (-) minus 4,5 meter. Elevasi pada Reservoar menjadi 461 meter, merupakan penjumlahan dari elevasi titik Reservoar tersebut, yaitu 401 meter ditambahkan dengan head pompa yang terpasang, yaitu: 60 meter. Sedangkan tekanan pada titik lainnya bernilai positif sebagaimana ditampilkan pada Gambar 3 dengan tekanan minimal adalah 18,25 meter pada titik 4 (Batas Kota). Untuk parameter kontrol kecepatan di dalam pipa, pada pipa 6 (titik 5 ke titik 6 ) terdapat nilai kecil dari $0,6 \mathrm{~m} / \mathrm{s}$, yaitu: $0,45 \mathrm{~m} / \mathrm{s}$, kondisi ini menjadi perhatian dalam operasional, karena memungkinkan terjadinya pengendapan.

Analisis eksisting tersebut dengan Epanet 2.0, menjelaskan terdapat hubungan kausalitas antara persoalan yang muncul di batas kota sebagai ujung wilayah pelayanan PDAM Kota Solok dengan kondisi tekanan yang relatif rendah, bahkan minus. Untuk menyelesaikan persoalan teknis tersebut dalam jangka waktu pendek (tidak dilakukan pengembangan

\begin{tabular}{|c|c|c|c|c|c|}
\hline \multicolumn{6}{|c|}{ 麗 File Edit View Project Report Window Help } \\
\hline \multicolumn{6}{|c|}{ 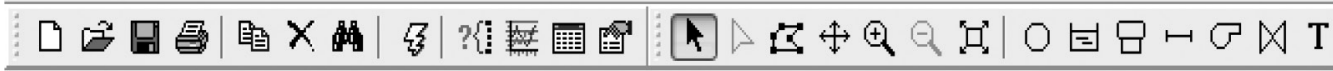 } \\
\hline Node ID & $\begin{array}{c}\text { Elevation } \\
\mathrm{m}\end{array}$ & $\begin{array}{l}\text { Demand } \\
\text { LPS }\end{array}$ & $\begin{array}{c}\text { Head } \\
m\end{array}$ & $\begin{array}{c}\text { Pressure } \\
\mathrm{m}\end{array}$ & \\
\hline Junc 1 & 401 & 5.00 & 456.02 & 55.02 & \\
\hline Junc 2 & 402 & 10.00 & 448.80 & 46.80 & \\
\hline Junc 3 & 402 & 6.00 & 443.20 & 41,20 & \\
\hline Junc 4 & 403 & 5.00 & 421.25 & 18.25 & \\
\hline Junc 5 & 403 & 2.00 & 402.82 & -0.18 & \\
\hline Junc 6 & 403 & 2.00 & 398.50 & $-4,50$ & \\
\hline Resvr P & 461 & -30.00 & 461.00 & 0.00 & \\
\hline
\end{tabular}

(a) Print screen tabel hasil analisis tekanan pada Sofware Epanet 2.0 


\begin{tabular}{|c|c|c|c|c|c|c|}
\hline \multicolumn{7}{|c|}{ 6. EPANET 2 - Eksisting Kel Simp Rumbionet - [Network Table - Links] } \\
\hline 骵 File Edit View Project & Report Windo & Help & & & & \\
\hline \multicolumn{7}{|c|}{ 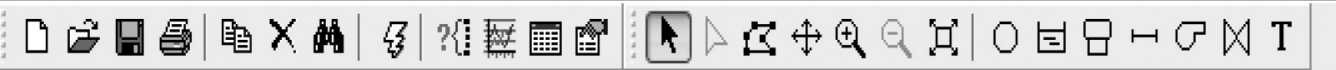 } \\
\hline Link ID & $\begin{array}{c}\text { Length } \\
\mathrm{m}\end{array}$ & $\begin{array}{c}\text { Diameter } \\
\mathrm{mm}\end{array}$ & Roughness & $\begin{array}{l}\text { Flow } \\
\text { LPS }\end{array}$ & $\begin{array}{c}\text { Velocity } \\
\mathrm{m} / \mathrm{s}\end{array}$ & $\begin{array}{c}\text { Unit Headloss } \\
\mathrm{m} / \mathrm{km}\end{array}$ \\
\hline Pipe 2 & 500 & 150 & 130 & 25.00 & 1.41 & 14.43 \\
\hline Pipe 3 & 1000 & 150 & 130 & 15,00 & 0.85 & 5.60 \\
\hline Pipe 4 & 1400 & 100 & 130 & 9.00 & 1.15 & 15,68 \\
\hline Pipe 5 & 1300 & 75 & 130 & 4.00 & 0.91 & 14,18 \\
\hline Pipe 6 & 1100 & 75 & 130 & 2.00 & 0.45 & 3.93 \\
\hline Pipe1 & 1000 & 200 & 130 & 30.00 & 0.95 & 4.98 \\
\hline
\end{tabular}

(a) Print screen tabel hasil analisis kecepatan pada Sofware Epanet 2.0

Gambar 3. Print screen tabel hasil analisis tekanan (a) dan kecepatan (b) pada Sofware Epanet 2.0 Sumber: Hasil analisis (2018)

layanan), diantaranya dapat dilakukan dengan 2 (dua) alternatif, yaitu:

1. Penggantian pipa distribusi pada ruas atau pipa 4 yang menghubungkan titik atau node 3 (Simpang 3 Sarang Walet) dengan node 4 (Batas Kota) dari diameter $100 \mathrm{~mm}$ menjadi diameter $150 \mathrm{~mm}$ jenis PVC, atau

2. Menambah spesifikasi head pompa pada reservoar yang ada di IPA KTK menjadi 70 -80 meter.

Adapun hasil running dari alternatif 1 (satu) dapat diilustrasikan pada Gambar 4. Tekanan kerja pada jaringan relatif baik, yaitu: 14,41 meter di ujung wilayah pelayanan. Sedangkan ditinjau dari kecepatan aliran terdapat nilai yang kurang dari 0,6 meter/detik, yakni di pipa 4 , yaitu 0,51 meter/detik dan pipa 6 , yaitu 0,45 meter/detik, dan ini menjadi perhatian untuk dilakukan pengurasan secara periodik. Sedangkan alternatif ke-2, tidak dilakukan analisa dengan Sofware Epanet 2.0, mengingat perlu kajian pembiayaan dan itu sangat dapat dilakukan.

\section{e. Perbandingan perhitungan program epanet dengan perhitungan manual.}

Perbandingan ini dilakukan untuk mengkoreksi dan memverifikasi ketelitian dan kebenaran analisis yang dilakukan dengan pendekatan sofware epanet dibanding pendekatan perhitungan secara manual. Angka ini sekaligus berfungsi sebagai faktor kalibrasi dari program epanet itu sendiri (Pramudiyanto, 2007). Perhitungan yang dilakukan secara manual terhadap kehilangan tekan atau headloss pada jaringan pipa menggunakan persamaan Hazen-Williams (Al-Layla,1980). Hal ini dikarenakan pada sofware epanet 2.0 ini juga menggunakan formula yang sama.

Persamaan Hazzen William adalah :

$H_{L}=\frac{10.74 x L}{D^{4,86}} \times\left(\frac{Q}{C}\right)^{1,85}$

Dimana : HL : headloss atau

kehilangan tekanan $(\mathrm{m})$

$$
\begin{array}{ll}
\mathrm{L} & : \text { panjang pipa, } \mathrm{m} \\
\mathrm{D} & : \text { diameter pipa, } \mathrm{m} \\
\mathrm{Q} & : \text { debit aliran, } \mathrm{m}^{3} / \text { detik } \\
\mathrm{C} & : \text { koefisien kekasaran pipa }
\end{array}
$$

Contoh perhitungan dapat diilustrasikan sebagai berikut :

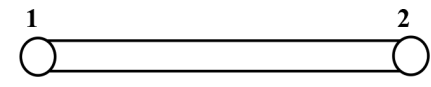

\section{Diketahui:}

Nama pipa : P.2, yakni titik Simpang Baringin Rambak ke Mesjid Syukur

$\begin{array}{ll}\text { L } & : \text { panjang pipa, } 500 \text { meter } \\ \text { D } & : \text { diameter pipa, } 150 \mathrm{~mm} \\ \text { C HW } & : 130 \\ \text { Q } & : \text { 25 liter/detik } \\ \text { HL.1 } & : 14,43 \text { meter/kilometer }\end{array}$
panjang pipa, $\mathrm{L}=0.5$ kilometer) atau 7,2 meter (hasil analisa epanet) 


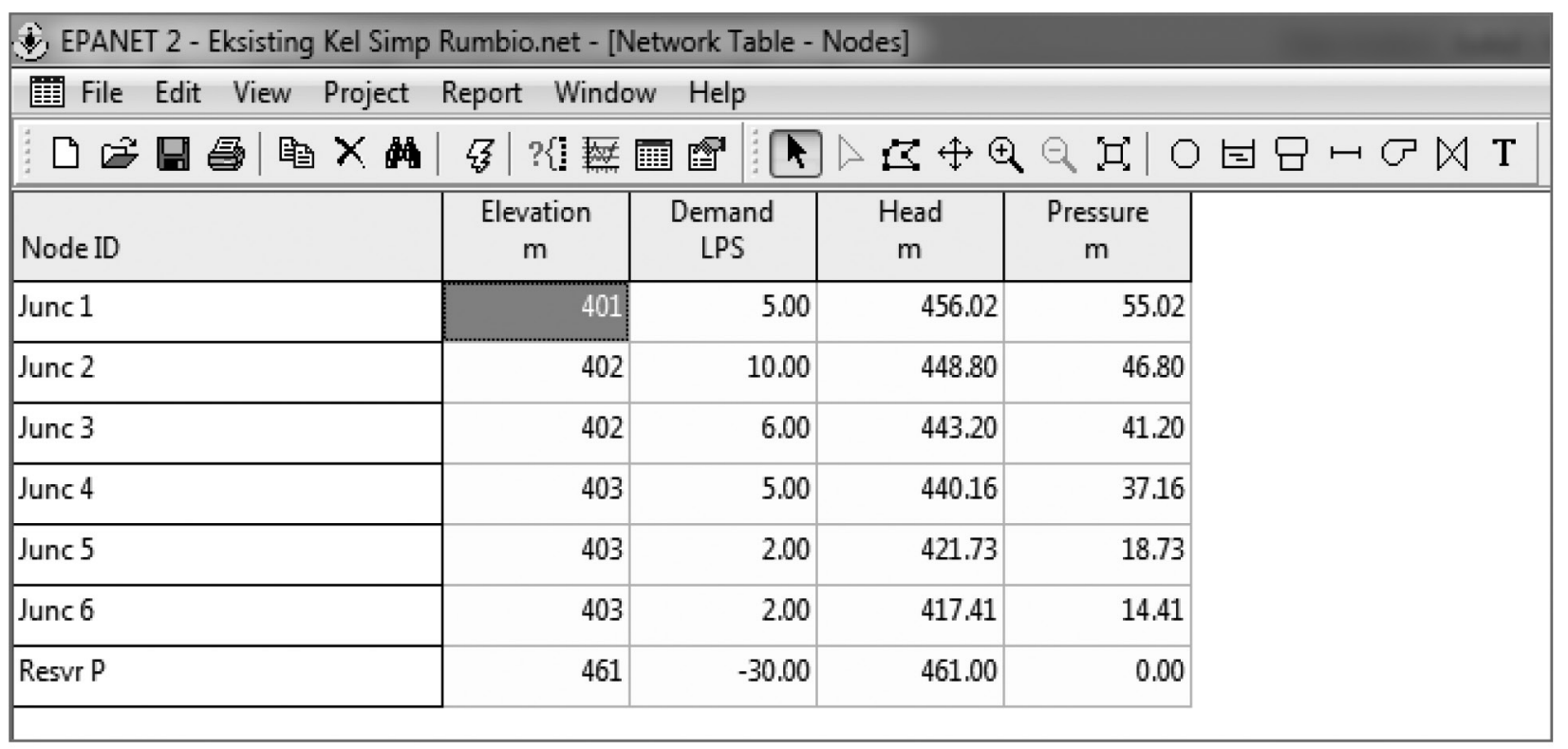

(a) Print screen tabel hasil analisis tekanan pada Sofware Epanet 2.0 dengan perbaikan alternatif 1

\begin{tabular}{|c|c|c|c|c|c|c|}
\hline \multicolumn{7}{|c|}{ 麗 File Edit View Project Report Window Help } \\
\hline \multicolumn{7}{|c|}{ 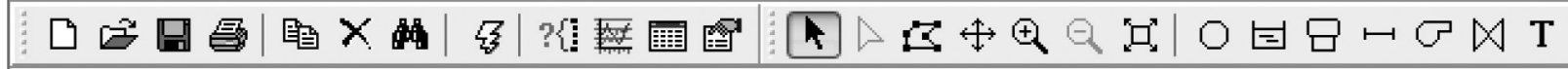 } \\
\hline Link ID & $\begin{array}{c}\text { Length } \\
\mathrm{m}\end{array}$ & $\begin{array}{c}\text { Diameter } \\
\mathrm{mm}\end{array}$ & $\begin{array}{l}\text { Flow } \\
\text { LPS }\end{array}$ & $\begin{array}{c}\text { Velocity } \\
\mathrm{m} / \mathrm{s}\end{array}$ & $\begin{array}{l}\text { Unit Headloss } \\
\mathrm{m} / \mathrm{km}\end{array}$ & \\
\hline Pipe 2 & 500 & 150 & 25.00 & 1.41 & 14.43 & \\
\hline Pipe 3 & 1000 & 150 & 15.00 & 0.85 & 5.60 & \\
\hline Pipe 4 & 1400 & 150 & 9.00 & 0.51 & 2.18 & \\
\hline Pipe 5 & 1300 & 75 & 4.00 & 0.91 & 14.18 & \\
\hline Pipe 6 & 1100 & 75 & 2.00 & 0.45 & 3.93 & \\
\hline Pipe 1 & 1000 & 200 & 30.00 & 0.95 & 4,98 & \\
\hline
\end{tabular}

(b) Print screen tabel hasil analisis kecepatan pada Sofware Epanet 2.0 dengan perbaikan alternatif 1

Gambar 4. Print screen tabel hasil analisis tekanan (a) dan kecepatan (b) pada Sofware Epanet 2.0 dengan perbaikan alternatif 1 Sumber: Hasil analisis (2018)

Penyelesaian :

$$
H_{L}=\frac{10.74 \times 500}{0,15^{4,86}} \times\left(\frac{0,025}{130}\right)^{1,85}
$$

$$
\text { HL.2 }=7,21 \text { meter }
$$

HL.1 dengan Epanet relatif sama dengan HL.2 dengan perhitungan manual, yaitu dengan selisih 0,01 (OK)

Hasil analisis yang dihasilkan pada perhitungan program epanet 2.0, diketahui tekanan sisa pada setiap titik pipa yang menjadi lokasi penyadapan, tidak terlalu berbeda jauh dengan perhitungan manual yang dilakukan. Perbedaan itu hanya sebesar 0,01 , sebagai contoh yaitu: nilai headloss pada hasil running epanet pada titik 2 adalah 7,2 meter, sedangkan dengan perhitungan manual dengan rumus Hazzen William diperoleh hasil 7,21. Dan begitu juga halnya dengan titik atau node pada pipa lain yang tidak berbeda jauh hasil perhitungan manual dengan hasil perhitungan epanet. 


\section{Kesimpulan dan Saran}

\section{a. Kesimpulan}

Pada kondisi eksisting, wilayah pelayanan Kelurahan Simpang Rumbio, PDAM Kota Solok, khususnya wilayah ujung dari pelayanan tidak mampu mengatasi masalah yang sering terjadi, yaitu: air tidak hidup. Hal ini disebabkan oleh nilai tekanan kerja pada jaringan bernilai negatif, yaitu: Titik 5 (Kantor Kejaksaan) dengan nilai (-) minus 0,18 meter dan Titik 6 (Saok Laweh) dengan nilai (-) minus 4,5 meter.

\section{b. Saran}

Untuk mengatasi masalah tersebut, maka dua alternatif yang dapat dapat dilakukan, yaitu:

1. Penggantian pipa distribusi pada ruas atau pipa 4 yang menghubungkan titik atau node 3 (Simpang 3 Sarang Walet) dengan node 4 (Batas Kota) dari diameter $100 \mathrm{~mm}$ menjadi diameter $150 \mathrm{~mm}$ jenis PVC, atau

2. Menambah spesifikasi head pompa pada reservoar yang ada di IPA KTK menjadi 70 - 80 meter

3. Menurunkan nilai kehilangan air

4. Serta melakukan penelitian lanjutan terhadap jaringan sistem distribusi eksisting ini, dengan menambahkan lingkup pengembangan dengan periode desain.

\section{Daftar Pustaka}

Al-Layla. 1980. Water Suplly Engineering Design. Ann Arbor Science.

Damanhuri, Enri, 1989, Pendekatan Sistem Dalam Pengendalian dan Pengoperasian Sistem Jaringan Distribusi Air Minum, Bandung: Jurusan Teknik Lingkungan, FTSP-ITB.

Giles, Ranald V. 1984. Mekanika Fluida dan Hidrolika Edisi Kedua. Erlangga : Jakarta.

Kamala, A dan Rao, Kanth. 1988. Environmental Engineering Water Supply Engineering and Polution.

Kota Solok, PDAM. 2018 "Laporan Teknik PDAM Kota SolokTahun 2018",

Linsley and Franzini, 1985, Teknik Sumber Daya Air (Terjemahan), Jakarta: Erlangga.

Materi Diklat, 1996, Materi Juknis Rencana Teknik Bidang Air Bersih, Dirjen Cipta Karya, DPU, Jakarta.

Moegijantoro, 1996. Air Untuk Kehidupan Manusia, Majalah Air Minum, edisi No. 85 / th. XXV Oktober 2001.
Noerbambang, Soufyan M. Morimura (Peter), Takeo, 1993, Perencanaan Dan Pemeliharaan Sistem Plambing, PT. Pradnya Paramita, Jakarta.

NSPM Kimpraswil .2002. Pedoman Petunjuk Teknis Manual.Vol. 6 (II dan III).

Pedoman Penyusunan Perencanaan Teknis Pengembangan Sistem Penyediaan Air Minum Tahun 2007.

Pramudiyanto. 2007. Program Komputer Untuk Analisis Aliran Pada Jaringan Pipa,

Rossman, Lewis A. 2000. Epanet 2 Users Manual Versi Bahasa Indonesia. Ekamitri Engineering.

Sarwoko, M. 1985. Penyediaan Air Bersih. Jurusan Teknik Lingkungan ITS. Surabaya. 